Roger Williams University

DOCS@RWU

2009

\title{
Once You Go Black: Choice, Desire, and the Black American Intellectual
}

Laura Mattoon D'Amore

Roger Williams University, Idamore@rwu.edu

Follow this and additional works at: https://docs.rwu.edu/fcas_fp

Part of the American Studies Commons

\section{Recommended Citation}

D’Amore, Laura Mattoon. 2009. "Once You Go Black: Choice, Desire, and the Black American Intellectual." The Journal of Popular Culture 42 (1): 186-188.

This Book Review is brought to you for free and open access by the Arts and Sciences at DOCS@RWU. It has been accepted for inclusion in Arts \& Sciences Faculty Publications by an authorized administrator of DOCS@RWU. For more information, please contact mwu@rwu.edu. 
ject" (2). These characters were constructed as evil because they played upon fears of racial and religious difference. The sexual Other represented a particularly terrifying presence because of its imperceptibility; unlike race, ethnicity, class or religion, which are often accompanied by a variety of distinguishable markers, the sexual Other could not be seen until he or she committed an actual act of deviance. According to Anolik, "the sexual Other is thus particularly and unavoidably dangerous, infiltrating the home and even the bed of the threatened Self" (4).

Unfortunately, Anolik's engaging introduction to the creation of the sexual Other in Gothic literature is the most cohesive and useful element in the book. While the essays are all interesting and relatively approachable, they lack a unity that would strengthen the authors' arguments. Indeed, one is left wondering what are the defining characteristics of Gothic literature and why one should examine it as a genre? These essays seem to disagree on the definition of Gothic literature and one essay suggests that the presence of a dangerous female Other in a narrative is sufficient to mark a text as Gothic. Accordingly, the essays explore an overly diverse set of texts including James Cameron's Aliens, Shakespeare's The Winter's Tale, Bronte's Jane Eyre, and Clive Barker's The Books of Blood. Regardless, the exploration of the process of othering sex and sexual difference in literature and film is well articulated throughout the collection and would be useful for those interested in popular cultural depictions of gender and sexuality, particularly for readers wishing to demonstrate the historical consistency of identity constructions in popular cultural forms.

Jay R. Clarkson Indiana State University No claim to original U.S. government works.

Once You Go Black: Choice, Desire, and the Black American Intellectual. Robert Reid-Pharr. New York: New York University Press, 2007.

The central thesis of Robert Reid-Pharr's Once You Go Black is that Americans are the agents of, not simply the products of, history. Applied to race, Reid-Pharr argues that the "Black American, quiet as it's kept, has had a substantial role in the creation of himself" (2). $\mathrm{He}$ claims the reason that race continues to burden identity-to be a 
cultural problem-is because we fail to situate it within its present moment, particularly by insisting that black American identity is perpetually defined by its link to the master/slave struggle, and that "the anguished cries of the slave are ultimately indistinct from the complicated musings of the contemporary artist" (37). Rather, he suggests that all the associated meanings of "blackness" in the nineteenth century are quite distinct from those of the "blackness" of the twentieth century (and so on). He wishes to show readers the "reality of their freedom," that "one might choose one's identity, indeed one's race" (7). The iterations, symbols, and texts that one chooses to represent identity carry that choice with them.

Race-represented-as-choice is both invigorating and unwieldy. Choosing one's ethnicity is something that many scholars have theorized about, as ethnic signifiers and traditions have become commercialized and easily consumed. However, they usually stop short at theorizing that one can choose "race," noting that there are certain assumptions that are always worn by the color of one's skin. Some of this is sociologically derived, some historically assumed, but all of it is largely considered inescapable. Reid-Pharr looks to the black American literary tradition for cues about how some black American intellectuals strained against assumptions about identity from within, as well as outside, the so-called "black community." He examines three relatively unknown (i.e., largely unaccepted) literary works by Richard Wright (The Long Dream), Ralph Ellison (Juneteenth), and James Baldwin (Just above $\mathrm{My}$ Head), and posits that by reading outside the black American literary canon-in this case, writings for which the authors were accused of losing touch with their audience, the mythical folk to whom they were supposedly connected through common roots-one finds more progressive ideas about identity.

To underscore the importance of looking beyond the focus of the dominant lens, Reid-Pharr also examines two well-known icons of American blackness, the Black Panther Party founder Huey Newton and Sweet Sweetback's Baadasssss Song (1971), a film directed by Melvin Van Peebles. They both rely on the amplification of identifiable metaphors of shared difference, thereby reinscribing the racial status quo. When such ideas find a wide audience, as they did with Newton and Sweetback, the notion of a shared black identity of a singular, static black community is popularized. Whereas the lesser known literary texts strained against the commonality of the black 
American experience, these mainstream articulations depend on those assumptions.

Reid-Pharr uses the historicist approach, arguing that the "action of both politics and culture always takes place at the surface and in the present" (172). In so doing, he joins the "insights of Black American cultural and literary criticism with those of queer theory," which not only "acknowledges that we perform racial difference but also that we perform our ignorance of this performance, that though 'race' comes freighted with all the weight of history, it is nonetheless farcical and obviously so" (6). The title of this book derives from the sexual joke "once you go black, you never go back." Culturally speaking, it refers to the inherent assumption that there exists a "blackness" which is different, and from which there is no escape. A forward thinking identity politics recognizes its culpability in its own representation of difference, and stops hiding behind historical inevitability.

Laura Mattoon D’Amore Boston University

"The Father of Baseball": A Biography of Henry Chadwick. Andrew J. Schiff. Jefferson, NC: McFarland, 2008.

Andrew J. Schiff's biography of Henry Chadwick (1824-1908) is a welcome addition to the bumper crop of books on the fertile subject of baseball. Generally regarded as baseball's father, Chadwick has gradually slipped into near obscurity. Schiff's major contribution has been to rescue his subject from that dark hole that is our throwaway culture. In a cogently argued thesis, Schiff persuades this reader that Chadwick matters. Among his many contributions to our national game, the most important is the invention of the scorecard and the application of statistics. In addition, Chadwick served as rule-maker, historian, publicist, promoter, and moralist. Baseball historian David Q. Voigt regarded him as a modern Moses (7).

Remarkably, this book germinated from a five-page term paper at Brooklyn College, morphed into an eighty-five-page master's essay, and now happily became a book. Professor Schiff highlights Chadwick's multifaceted roles in baseball's evolution principally from the British 